CONCISE REPORT

\title{
Human parvovirus B19, varicella zoster virus, and human herpes virus 6 in temporal artery biopsy specimens of patients with giant cell arteritis: analysis with quantitative real time polymerase chain reaction
}

\author{
R Álvarez-Lafuente, B Fernández-Gutiérrez, J A Jover, E Júdez, E Loza, D Clemente, \\ J A García-Asenjo, J R Lamas
}

\begin{abstract}
Objective: To evaluate the role of parvovirus B19 (B19), varicella zoster virus (VZV), and human herpes virus 6 (HHV-6) in the aetiopathology of giant cell arteritis (GCA). Methods: Temporal artery biopsy specimens from 57 patients with GCA and 56 controls were investigated. DNA was obtained by biopsy, and quantitative real time polymerase chain reaction assay performed to establish the prevalence and viral load of B19, VZV, and HHV-6. Amplification of the human $\beta$-globin gene was used as internal positive control.

Results: (a) B19 was detected in $31 / 57$ (54\%) patients (median viral load 45.2 (25th-75th centiles 0-180.2) copies/ $\mu \mathrm{g}$ DNA) v $21 / 56$ (38\%) controls (median viral load 0 (0-66.7) copies/ $\mu \mathrm{g}$ of DNA; $p=0.07$ for DNA prevalence, $\mathrm{p}=0.007$ for viral load. Among $31 \mathrm{~B} 19$ positive samples, 21 (68\%) patients with biopsy proven GCA had $>10^{2}$ B19 copies/ $\mu$ g of DNA $v 5 / 21$ (24\%) controls; $p=0.001$. (b) No significant difference was found for VZV $(p=0.94$ for DNA prevalence; $p=0.76$ for viral load) and HHV-6 ( $p=0.89$ for DNA prevalence; $p=0.64$ for viral load) in the GCA group compared with controls.

Conclusion: B19 may have a role in the aetiopathology of GCA, particularly in those patients with high viral load; no evidence was found for VZV and HHV-6.
\end{abstract}

$\mathrm{R}$ ecent studies have suggested that persistent infections may be involved in the pathogenesis of giant cell arteritis (GCA), although evidence has been inconclusive. GCA is a disease of unknown aetiology characterised by acute inflammation affecting medium and large arteries in elderly people, with a predilection for branches of the temporal arteries. Multiple environmental and genetic factors probably play a part in susceptibility to GCA. ${ }^{1}$ Although certain HLA-DR alleles are correlated with GCA, ${ }^{2}$ genetic factors are insufficient to explain the marked variation in geographic prevalence ${ }^{3}$ and the temporal fluctuation in the incidence of the disease. ${ }^{1}$ Different findings suggest that infectious agents may be involved in the pathogenesis of the disease: parvovirus B19 (B19), ${ }^{45}$ human herpes virus 6 $(\mathrm{HHV}-6),{ }^{6}$ and varicella zoster virus $(\mathrm{VZV}) .{ }^{78}$

This study aimed at determining B19, VZV, and HHV-6 DNA prevalence and viral loads in temporal artery biopsy (TAB) specimens of patients with GCA, to analyse the hypothesis that an environmental factor may have a role in the pathogenesis of GCA.

\section{PATIENTS AND METHODS}

\section{Patients and specimens}

We examined TAB specimens from 113 patients suspected of having GCA. Patients, before biopsy, had taken either no drugs for GCA or corticosteroids for less than 2 weeks. Fifty seven patients (38 women) had biopsy proven GCA (GCA group) and 56 patients (40 women), had no histological evidence of vasculitis (control group). The mean (SD) age of the GCA group was 78 (8.7) years and of the controls 77.6 (7.9) years; $p=0.75$. Patients were recruited from the rheumatology service of Hospital Clinico San Carlos (HCSC), Madrid. TAB specimens were collected at the pathology service of HCSC. The investigators who carried out the DNA analysis did not know the clinical and histological diagnoses. The study was approved by the local ethics committee.

\section{DNA extraction}

Ten sections 4-6 $\mu \mathrm{m}$ thick taken from each biopsy specimen were deparaffinised by incubating for 5 minutes each in two changes of xylene and for 5 minutes in absolute ethanol. The specimens were dried and rehydrated in distilled water. The DNA was then extracted using Qiagen columns (QIAamp DNA Mini Kit; Qiagen Inc), according to the protocols supplied by the manufacturer; then was quantified by spectrophotometry. In all samples, DNA extraction was successful, as confirmed by the presence of sufficient and non-degraded human DNA.

\section{Quantitative real time PCR}

The DNAs were analysed by quantitative real time polymerase chain reaction (q-rtPCR) for the presence of B19, VZV, and HHV-6 genomes and the human $\beta$-globin gene as internal control (to ensure that DNAs were suitable for DNA amplification). Primers, TaqMan probes, and reaction conditions for the q-rtPCR assay for VZV, ${ }^{9} \mathrm{HHV}-6,{ }^{10}$ and $\beta$-globin ${ }^{11}$ have been described previously. A commercial kit (Artus B19 RG RealArt PCR kit) was used for the B19 assay. For each virus three reactions were carried out. The quantitative assessment was performed in a Rotor-Gene 2000 real time cycler (Corbett Research. Sydney. Australia). Cycling conditions were preincubation at $95^{\circ} \mathrm{C}$ for 15 minutes to activate AmpliTaq gold DNA polymerase, then two step thermocycling (denaturation and anneal/extension) was performed for 40 cycles. The q-rtPCR for B19 was carried out according to the manufacturer's protocol. With these

Abbreviations: B19, parvovirus B19; GCA, giant cell arteritis; HHV-6, human herpes virus 6 ; $q-r+P C R$, quantitative real time polymerase chain reaction; $T A B$, temporal artery biopsy; VZV, varicella zoster virus 


\begin{tabular}{|c|c|c|c|}
\hline & $\begin{array}{l}\text { GCA } \\
(n=57)\end{array}$ & $\begin{array}{l}\mathrm{CG}^{*} \\
(\mathrm{n}=56)\end{array}$ & $p$ \\
\hline B19 & $31(54)$ & 21 (38) & 0.07 \\
\hline HHV-6 & 20 (35) & 19 (34) & 0.89 \\
\hline VZV & $18(32)$ & $18(32)$ & 0.94 \\
\hline
\end{tabular}

conditions, the sensitivity of the assay was one copy for all the viruses and the internal control.

The final DNA copy number was determined by calculation of the number of PCR cycles necessary for a standard curve of known amounts (10 000, 1000, 100, 10, and 1 DNA copies) of purified and quantified B19, VZV, and HHV-6 DNA to cross a fluorescent threshold and interpolation of the unknowns. Each point was obtained in triplicate and we repeated the standard curve for each of the PCRs.

These data were sent to a desktop PC and were displayed in real time on the screen as fluorescence versus cycle number. Threshold cycle or computed tomography and quantification of DNA for each sample (standard curve points and unknowns) were performed by the software provided with the Real-Time Cycler Rotor-Gene 2000.

\section{Data analysis}

Categorical variables are presented as a frequency distribution and quantitative variables as a median. The $\chi^{2}$ test was used to compare categorical variables. Differences between groups were analysed using the Mann-Whitney $U$ test for quantitative variables. A two sided p value of 0.05 was the criterion for significance in all cases.

\section{RESULTS \\ Comparative study of B 19, VZV, and HHV-6 DNA prevalence}

Table 1 shows the DNA prevalence of B19, VZV, and HHV-6 in TAB specimens collected from patients with biopsy proven GCA and from controls. B19 DNA was detected in 31/57 (54\%) TAB specimens with histological evidence of GCA, and in $21 / 56(38 \%)$ TAB specimens with no histological evidence of GCA; this difference was almost significant $(p=0.07)$. The DNA prevalence of VZV and HHV-6 was similar in the GCA and control groups.

Comparative study of B 19, VZV, and HHV-6 viral load There was a significant difference (table 2) in B19 median viral load between TAB specimens in patients with biopsy proven GCA (45.2 genomes/ $\mu$ g of DNA) and TAB specimens in the control group ( 0 genomes/ $\mu$ g of DNA; $p=0.007)$. Among the patients with GCA we found two TAB specimens with $>10^{3}$ B 19 genomes/ $\mu$ g of DNA (table 3). In 19 (61\%) patients with biopsy proven GCA the viral load ranged between $10^{2}$ and $10^{3} \mathrm{~B} 19$ genomes/ $\mu$ g of DNA, compared with only five $(24 \%)$ patients in the control group; $\mathrm{p}=0.001$.

For HHV-6 and VZV, we found a median viral load of 0 genomes/ $\mu$ g of DNA for both viruses, in both groups. We did not find any TAB specimen with more than $10^{3}$ genomes/ $\mu \mathrm{g}$ of DNA for HHV-6 or VZV (table 3).

\section{DISCUSSION}

Parvovirus B19 is a non-enveloped icosahedral DNA virus discovered fortuitously in 1975 in the United Kingdom. In recent years, there has been controversy about the
Table 2 B19, VZV, and HHV-6 viral load in patients with GCA and control group

\begin{tabular}{llll}
\hline Viral load $^{*}$ & GCA & CG & p \\
\hline B19 & $45.2(0-180.2)$ & $0(0-66.7)$ & 0.007 \\
HHV-6 & $0(0-47.8)$ & $0(0-37.7)$ & 0.64 \\
VZV & $0(0-25.8)$ & $0(0-26.4)$ & 0.76 \\
\hline
\end{tabular}

*Viral loads are expressed in genomes/ $\mu$ g of DNA as the median (25th75th centiles).

$C G$, control group

epidemiological data of studies that analysed the role of B19 in the aetiology of GCA, the most common form of systemic vasculitis in adults, which preferentially affects large and medium sized arteries in patients over the age of 50 . One case of B19 persistent infection in a patient with GCA with high titres and presence of viral genomes in the blood was reported by Staud and Corman in 1996. ${ }^{12}$ In 1999 a study by Gabriel et al was published supporting the potential role of B19 in the disease. ${ }^{4}$ They examined TAB tissue from 50 patients using PCR and their results indicated a statistically significant association between histological evidence of GCA and the presence of B19 DNA in TAB tissue $(p=0.0013)$. However, other authors did not reach the same conclusions ${ }^{13}{ }^{14}$ : Salvarani et al reported that B19 seems to be an innocent bystander commonly present in the arteries of elderly people, ${ }^{13}$ and Helweg-Larsen et al investigated 30 temporal artery biopsy specimens and the result was negative in all of them. ${ }^{14}$

In this study we describe a significant association between the high viral load of $\mathrm{B} 19$ in temporal arteries and histological evidence of GCA. To our knowledge, this study is the first to investigate the B19 viral load in the temporal arteries of patients with GCA by q-rtPCR. Although a clear tendency was observed for a higher prevalence of B19 DNA in patients with GCA (54\%) compared with controls (38\%), it did not reach significance $(\mathrm{p}=0.07)$. However, when we analysed the B19 viral load of the 31 patients with biopsy proven GCA with B19 genomes in their TAB specimens (table 3), two (6\%) had high levels of viral load $\left(>10^{3}\right.$ copies/ $\mu \mathrm{g}$ of DNA), $19(61 \%)$ had $10^{2}-10^{3} \mathrm{~B} 19$ copies/ $\mu \mathrm{g}$ of DNA, and $10(32 \%) 10^{1}-10^{2}$ copies/ $\mu$ g of DNA. Among 21 patients without histological evidence of vasculitis, only five $(24 \%)$ had $10^{2}-10^{3} \mathrm{~B} 19$ copies/ $\mu \mathrm{g}$ of DNA. The difference in the number of specimens with more than $10^{2}$ copies between both groups is significant $(p=0.001)$. Nevertheless, our findings did not confirm any association between histological evidence of GCA and the presence of VZV and HHV-6 DNA in $\mathrm{TAB}$ tissue. Interestingly, we found that about $30 \%$ of $\mathrm{TAB}$ specimens, with the exception of $54 \%$ in the case of B19 in the GCA group, were positive for some viral DNA. This high prevalence of viral DNA might be related to the advanced age of patients and/or to the particular characteristics of arterial tissue but, in most cases, viruses seem to be only innocent bystanders.

In any event, B19 DNA seems to be commonly present in TAB specimens of elderly people with GCA, where it probably persists for years or decades after primary infection; this hypothesis is further supported by the finding that the cellular receptor for B19 (erythrocyte P antigen) is also expressed on endothelial cells. ${ }^{15}$ However, although the virus is probably latent in the control group, among patients with biopsy proven GCA a reactivation of B19 latent infection may be a possible disease trigger, particularly in those patients with high viral load.

More effort is needed to understand the mechanisms of the viral reactivation and their relationships with the inflammatory process of the disease: does B19 reactivation lead to 
Table 3 B19, VZV and HHV-6 viral load ranges in positive patients with GCA and controls

\begin{tabular}{|c|c|c|c|c|c|c|}
\hline \multirow[b]{2}{*}{ Viral load range* } & \multicolumn{2}{|l|}{ B19 } & \multicolumn{2}{|l|}{ HHV-6 } & \multicolumn{2}{|l|}{ VZV } \\
\hline & $\begin{array}{l}\text { GCA } \\
(n=31)\end{array}$ & $\begin{array}{l}C G \\
(n=21)\end{array}$ & $\begin{array}{l}\text { GCA } \\
(n=20)\end{array}$ & $\begin{array}{l}\text { CG } \\
(n=19)\end{array}$ & $\begin{array}{l}\text { GCA } \\
(n=18)\end{array}$ & $\begin{array}{l}G C \\
(n=18)\end{array}$ \\
\hline $\begin{array}{l}10^{1}-10^{2} \\
10^{2}-10^{3} \\
>10^{3}\end{array}$ & $\begin{array}{c}10(32) \\
19(61) \\
2(6)\end{array}$ & $\begin{array}{c}16(76) \\
5(24) \\
0(0)\end{array}$ & $\begin{array}{l}15(75) \\
5(25) \\
0(0)\end{array}$ & $\begin{array}{c}16(84) \\
3(16) \\
0(0)\end{array}$ & $\begin{array}{c}14(78) \\
4(22) \\
0(0)\end{array}$ & $\begin{array}{c}18(100) \\
0(0) \\
0(0)\end{array}$ \\
\hline
\end{tabular}

inflammation or inflammation leads to B19 reactivation? Further studies are required to evaluate the exact role of B19 in the aetiopathology of GCA.

\section{ACKNOWLEDGEMENTS}

Supported by grants from FIS 01/0587 and Schering \& Plough.

\section{Authors' affiliations}

R Álvarez-Lafuente, B Fernández-Gutiérrez, J A Jover, E Júdez, E Loza,

D Clemente, J R Lamas, Rheumatology Service, Hospital Clínico San Carlos, C/ Prof Martín Lagos s/n 28040 Madrid, Spain

J A García-Asenjo, Pathology Service, Hospital Clínico San Carlosm, C/ Prof Martín Lagos s/n 28040 Madrid, Spain

Correspondence to: Dr B Fernández-Gutiérrez; bfernandez.hcsc@ salud.madrid.org

Accepted 10 September 2004

\section{REFERENCES}

1 Salvarani C, Gabriel SE, O'Fallon WM, Hunder GG. The incidence of giant cell arteritis in Olmsted County, Minnesota: apparent fluctuations in a cyclic pattern. Ann Intern Med 1995;123:192-4.

2 Weyland CM, Schonberger J, Oppitz U, Hunder NN, Hicok KC, Goronzy JJ. Distinct vascular lesions in giant cell arteritis share identical T cell clonotypes. $J$ Exp Med 1994;179:951-60.

3 Nordborg E. Epidemiology of biopsy-positive giant cell arteritis: an overview. Clin Exp Rheumatol 2000;18:S15-17.
4 Gabriel SE, Espy M, Erdman DD, Bjornsson J, Smith TF, Hunder GG. The role of parvovirus B19 in the pathogenesis of giant cell arteritis: a preliminary evaluation. Arthritis Rheum 1999:42:1255-8.

5 Russo MG, Waxman J, Abdoh AA, Serebro LH. Correlation between infection and the onset of the giant cell (temporal) arteritis syndrome. A trigger mechanism? Arthritis Rheum 1995; 38:374-80.

6 Toyabe S, Harada W, Suzuki H, Hirokawa T, Uchiyama M. Large vessel arteritis associated with human herpesvirus 6 infections. Clin Rheumatol 2002;21:528-32

7 Mitchell BM, Font RL. Detection of varicella zoster virus DNA in some patients with giant cell arteritis. Invest Ophthalmol Vis Sci 2001;42:2572-7.

8 Berger TM, Caduff JH, Gebbers JO. Fatal varicella-zoster virus antigenpositive giant cell arteritis of the central nervous system. Pediatr Infect Dis $J$ 2000;19:653-6.

9 Druce J, Catón M, Chibo D, Minerds K, Tyssen D, Kostecki R, et al. Utility of a multiplex PCR assay for detecting herpesvirus DNA in clinical samples. J Clin Microbiol 2002:40:1728-32.

10 Nitsche A, Müller CW, Radonic A, Landt O, Ellerbrok H, Pauli G, et al. Human herpesvirus 6A DNA is detected frequently in plasma but rarely in peripheral blood leukocytes of patients after bone marrow transplantation. J Infect Dis 2001;183:130-3.

11 Shibata D. PCR-based detection of the herpesviruses and the papillomaviruses. In: Ehrlich GD, Greenberg SJ, eds. In: PCR-based diagnostics in infectious disease, 1 st edn. Boston: Blackwell Scientific Publications, 1994:455-81.

12 Staud R, Corman LC. Association of parvovirus B19 infection with giant cell arteritis. Clin Infect Dis 1996;22:1123.

13 Salvarani C, Farnetti E, Casali B, Nicoli D, Wenlan L, Bajocchi G, et al. Detection of parvovirus $B 19$ DNA by polymerase chain reaction in giant cell arteritis: a case-control study. Arthritis Rheum 2002;46:3099-101.

14 Helweg-Larsen J, Tarp B, Obel N, Baslund B. No evidence of parvovirus B19, Chlamydia pneumoniae or human herpes virus infection in temporal artery biopsies in patients with giant cell arteritis. Rheumatology (Oxford) 2002;41:445-9.

15 Brown KE, Anderson SM, Young NS. Erythrocyte P antigen: cellular receptor for B19 parvovirus. Science 1993;262:114-17. 